DOI: $10.17148 / I A R J S E T .2021 .8916$

\title{
An Overview of Application for N.B.A Accreditation to Diploma Level Polytechnic Institutions in India and Advantages
}

\author{
Rajkumar Sreepadapu ${ }^{1}$, Swathi Polasa ${ }^{2}$ \\ ${ }^{1}$ Head of Mechanical Engineering Section, Sanjay Gandhi Government Polytechnic - \\ Adilabad-Telangana State, India \\ ${ }^{2}$ Senior Lecturer in Electrical and Electronics Engineering, Government Polytechnic - \\ Nirmal-Telangana State, India
}

\begin{abstract}
NBA" stands for the National Board of Accreditation which is an accreditation agency representing India in the Washington Accord (WA). The Washington Accord is an agreement between bodies that accredit or recognize higher-level engineering qualifications.NBA is one such autonomous accrediting body in India, which deals with the accreditation of engineering and various technical institutions based on the quality of education being offered. The guidelines outlined by the NBA act as parameters to certify institutions. Any higher education institution (HEI) willing to apply and successfully get accredited from the NBA needs to ensure that all guidelines are followed strictly and every document or information that needs to be submitted is free from any errors and is $100 \%$ authentic. The accreditation of NBA helps higher educational institute to know its strengths, weaknesses and opportunities. NBA accreditation helps institutes to get financial assistance from various agencies. The accreditation gives higher learning institutes a new sense of direction and identity. The NBA process enables the institutions to identify and overcome the teaching-learning gaps and develop strategies that maximize the student learning outcomes. It urges the institutions to initiate quality improvement programs, activities, etc. by motivating the faculty to participate actively in academic activities.

Applying for NBA and submission of SAR (Self Assessment Report) includes

1. $\quad$ Register on eNBA portal and fill Prequalifier and pay Partial fee.

2. Fill SAR online in the defined format on portal.

3. Login to eNBA portal and submit the SAR.

4. Pay the fee.

5. Provide 3 dates for NBAs site visit for inspection.

6. NBA Peer Team Visit

7. Analysis \& Evaluation by Committee Members

In this paper an attempt is made on overview of application for NBA accreditation to Diploma level Polytechnic institutions in India and advantages are highlighted.
\end{abstract}

Keywords: NBA, Accreditation, SAR, Diploma institutes, Advantages, OBE

\section{INTRODUCTION}

An international agreement between bodies responsible for accrediting engineering degree programmes is termed as Washington accord[2]. The signatories of this accord are committed to development and recognition of good practice in engineering education. The activities of the Accord signatories (for example in developing exemplars of the graduates' profiles from certain types of qualification) are intended to assist growing globalization of mutual recognition of engineering qualifications. The special focus of Washington Accord is on academic programmes which deal with the practice of engineering at the professional level.India became a permanent signatory member of the Washington Accord (WA)[2] on $13^{\text {th }}$ June 2014. This will facilitate Indian engineering graduates get a level playing field in postgraduate studies and jobs in the United States, the UK and many other important countries. The accord was signed by the National Board of Accreditation (NBA) on behalf of India. The new accreditation process is more outcomes based, unlike the earlier input based structure. Outcome based education is targeted at achieving desirable outcomes (knowledge, skill, attitude and behaviour) at the end of the Program. Indian government made accreditation of technical courses mandatory. NBA was initially established by AICTE (All India Council of Technical Education) under section 10(u) of AICTE act in 1994. This was done to assess the qualitative competence of the Programs offered by educational 


\section{International Advanced Research Journal in Science, Engineering and Technology}

Vol. 8, Issue 9, September 2021

DOI: 10.17148/IARJSET.2021.8916

institutes from diploma level to Post-graduate level in Engineering and Technology, Management, Architecture, Pharmacy and related disciplines. With effect from 7th January 2010, NBA came into existence as independent autonomous body.

NBA conducts evaluation of programs of technical institutes on the basis of laid down norms which may include institutional Mission, Vision, and objectives, organization and governance, infrastructure facilities, quality of teaching and learning, curriculum design and review, support services (library, laboratory, instrumentation, computer facilities, etc.) and any other aspect as decided by the General Council and / or Executive Committee of NBA, which will help the graduates produced by the institutions as per industry requirements in line with best international practices. Based on evaluation, a score is given to the Program. Depending on the score, the duration of eligibility of provisional accreditation is decided. Accreditation Manual 2019 for Diploma Engineering programmes is available at the NBA website [3].

\section{WHY ACCREDITATION?}

- $\quad$ To promote and recognize excellence in technical education in Engineering Institutes (diploma, UG and PG)

- Institutions, students, employers and the public at large benefit from the external verification of the processes carried out through the accreditation process.

- Confidence and assurance of the quality to the stakeholdersincludingstudentsStakeholders(Faculty,Students,Alumni,Employers/Industry,Parents)

- Institutes get benefit from the process of continuous quality improvement

\section{ADVANTAGES OF NBA TO THE INSTITUTE:}

The process of accreditation helps in realizing a number of benefits, like

$\checkmark$ Helps the Institution to know its strengths, weaknesses and opportunities

$\checkmark \quad$ Initiates Institutions into innovative and modern methods of pedagogy

$\checkmark \quad$ Gives Institutions a new sense of direction and identity

$\checkmark \quad$ Provides society with reliable information on quality of education offered

$\checkmark \quad$ Promotes intra and inter-institutional interactions

Only Programs are accredited, not institutes or colleges or Universities. Programs are like Diploma in Mechanical Engineering, Diploma in Computer Science Engineering etc. Set of courses are included in a program. Courses can be of Theory/ Lab/ Theory +Lab. Example of course is Basic Mathematics, Basic English etc.

\section{HOW TO APPLY FOR NBA TO A DIPLOMA ENGINEERING PROGRAM?}

Applying for NBA and submission of SAR (Self Assessment Report) includes

1. Register on eNBA portal and fill Prequalifier and pay Partial fee.

2. Fill SARonline in the defined format on portal.

3. Login to eNBA portal and submit the SAR.

4. Pay the fee.

5. Provide 3 dates for NBAs site visit for inspection.

6. NBA Peer Team Visit

7. Analysis \& Evaluation by Committee Members

Prequalifier includes the following:

- $\quad$ Details of the institute (year, type, ownership, programs offered etc. )

- $\quad$ Details of the program (as per AICTE approval)

- $\quad$ Students admission details from last 3 years (Admissions should be min $50 \%$ or $60 \%$ )

- $\quad$ Faculty details

- $\quad$ Student Faculty Ratio (Should be min 1:30 or 1:25)

- Two batches should have been passed out

SAR is Self assessment report. NBA-SAR data must be prepared as per format and is to be submitted online. We can download the latest 2019 manual for Diploma Engineering programmes from the website https://www.nbaind.org[3]. SAR comprises of PART A-Institutional information, PART B-Criteria summary and PART C - Declaration of the institution. In Part B, there are seven Program level criteria (Criterion1 to 7) and two Institute level criteria (Criterion 8 to 9$)$.

Criterion 1: Vision, Mission, Program Educational Objectives (50 points): Institution and Department level Vision, Mission and Program Educational Objectives are to be developed. Vision should state what you want to become in few 


\section{International Advanced Research Journal in Science, Engineering and Technology}

Vol. 8, Issue 9, September 2021

DOI: 10.17148/IARJSET.2021.8916

years. Mission should state how to achieve it. PEOs should state why the students join the institute. PEOs are to be mapped to Mission statements.

Criterion 2: Program Curriculum and Teaching -Learning Processes (200 points): We can identify curricular gaps and take necessary actions to fill the gaps. Preparation of course files which contains:

a. $\quad$ Timetable, showing in which slot the course is taken

b. Syllabus with COs, CO-PO-PSO matrix

c. Lecture plan/Lesson plan for all the lectures

d. Any other teaching tools/hand written materials/slides used

e. Assignment/class test/final exam question papers

f. Model answer scripts of students for all the tests conducted7. Results analysis-excel sheet

g. Out comes assessment report-CO assessment

h. Attendance record-actual

Criterion 3: Course Outcomes and Programme Outcomes (100 points): From gradate attributes, seven POs are suggested for Diploma Engineering programmes. Programme Outcomes are Abilities expected from the students after completion of the Programme. 2 to 4 Programme specific outcomes (PSO) must be developed. Programme Outcomes for Diploma are listed below:

1. Basic and Discipline specific knowledge: Apply knowledge of basic mathematics, science and engineering fundamentals and engineering specialization to solve the engineering problems.

2. Problem analysis: Identify and analyse well-defined engineering problems using codified standard methods.

3. Design/ development of solutions: Design solutions for well-defined technical problems and assist with the design of systems components or processes to meet specified needs.
Tools,
Experimentation
and
Testing:

Applymodernengineeringtoolsandappropriatetechniquetoconductstandardtestsand measurements.

5. Engineering practices for society, sustainability and environment: Apply appropriate technology in context of society, sustainability, environment and ethical practices.

6. Project Management: Use engineering management principles individually, as a team member or a leader to manage projects and effectively communicate about well-defined engineering activities.

7. Life-long learning: Ability to analyze individual needs and engage in updating in the context of technological changes.

We have to list all the Course outcomes. Course Outcomes are the abilities expected at the end of the course from the student. Maximum number of COs for a course to be written is 6. CO-PO mapping matrix must be prepared.

Assessment can be done in direct or indirect method. Indirect assessment is done by taking feedback. There can be two types of feedback forms.

A. Course wise feedback form(for students)

B. $\quad$ Course wise feedback form (for stake holders)

Alumni feedback may also be taken. Calculation of the $\mathrm{CO}$ attainment and PO attainment is to be done referring to the NBA-SAR format/Manual.

\section{Criterion 4: Student's Performance (200 points)}

- The educational institution should monitor the academic performance of its students carefully. The requirements of the programme should be made known to every student.

- The educational institution must provide student support services including counselling/tutoring/mentoring.

- The institute shall provide the required information for three complete academic years for admission intake in the programme, admission quality, success rate, academic performance, placement and higher studies and professional activities.

\section{Criterion 5: Faculty Information and Contributions (150 points)}

- The faculty members should possess adequate knowledge/expertise to deliver all the curricular contents of the programme.

- The faculty must be engaged in activities outside their teaching duties like professional development, curriculum development, student mentoring/counselling, administrative work, training and placement of students, interaction with industry and professional practitioners.

- The number of faculty members must be sufficiently large in proportion to the number of students, 


\section{International Advanced Research Journal in Science, Engineering and Technology}

Vol. 8, Issue 9, September 2021

DOI: $10.17148 /$ IARJSET.2021.8916

so as to provide adequate levels of faculty-student interaction.(SFR Student faculty ratio - Diploma Engineering Programs: 30:1 for the accreditation of 3years).

\section{Criterion 6: Facilities and Technical Support (100 points)}

- The institution must provide adequate infrastructural facilities to support the achievement of the student learning outcomes.

- Classrooms, tutorial rooms, meeting rooms, seminar halls, conference halls, faculty rooms and laboratories must be adequately furnished to provide an environment good for learning.

- Modern teaching aids such as digital interactive boards, multimedia projectors etc., should be in place to facilitate the teaching-learning process so that student learning outcomes are achieved.

\section{Criterion 7: Continuous Improvement (75 points)}

- Actions taken based on the results of evaluation of each of the POs and PSOs attainment, Actions for improvement.

- The institute shall provide the required information for:

$\checkmark \quad$ Improvement in success index of students without the backlog

$\checkmark \quad$ Improvement in placements and higher studies

$\checkmark \quad$ Improvement in academic performance in final year

$\checkmark$ Internal academic audits to review complete academics and corrective actions on continuous basis

$\checkmark \quad$ Improvement in faculty Qualifications, publications etc.,

$\checkmark \quad$ New facility created in the program

\section{Criterion 8: Student Support Systems (50 points)}

- Mentoring system to help at individual level

- Feedback analysis and reward /corrective measures taken, if any

- Feedback on facilities

- $\quad$ Career Guidance, Training, Placement

$\checkmark \quad$ Availability, Management, Effectiveness

- Entrepreneurship Cell/Technology Business Incubator

$\checkmark \quad$ Availability, Management, Effectiveness

\section{Criterion 9: Governance, Institutional Support and Financial Resources (75)}

- $\quad$ Organization, Governance and Transparency

- $\quad$ Governing body

- $\quad$ Administrative setup

- $\quad$ Functions of various bodies

- $\quad$ Recruitment and promotional policies

- $\quad$ Decentralization in working and grievance redressal mechanism

- Delegation of financial powers

- Transparency and availability of correct/unambiguous information in public domain

Total 1000 points can be scored from all the above mentioned criteria. Requirements to achieve Award of Accreditation for Six Years:

$\checkmark \quad$ Program should score greater than or equal to 750 points in aggregate out of 1000 points with minimum score of 60 per cent in mandatory fields (criteria 4 to 6 ).

$\checkmark \quad$ Program should meet all the essential parameters for Accreditation of 3 years.

\section{Requirement to achieve Award of Accreditation for Three Years:}

$\checkmark \quad$ Program should score greater than or equal to 600 points.

$\checkmark \quad$ The admissions in the diploma program under consideration should be more than or equal to 50 per cent, averaged over three academic years i.e. Current Academic Year (CAY), Current Academic Year Minus One (CAYM1) and Current Academic Year Minus Two (CAYM2). 


\section{International Advanced Research Journal in Science, Engineering and Technology}

Vol. 8, Issue 9, September 2021

\section{DOI: 10.17148/IARJSET.2021.8916}

$\checkmark \quad$ Faculty Student Ratio in the department of the program under consideration should be less than or equal to 1:30, averaged over three academic years i.e. Current Academic Year (CAY), Current Academic Year Minus One (CAYM1) and Current Academic Year Minus Two (CAYM2).

\section{No Accreditation of the Programs:}

If the program fails to meet the criteria for award of three years accreditation, it is awarded "Not Accredited" status.

\section{NBA Peer Team Visit:}

Although it may not be possible to adequately describe all the factors to be assessed during the on-site visit, some of the common ones are:

(i) Outcome of the education provided

(ii) Quality assurance processes, including internal reviews

(iii) Assessment

(iv) Activities and work of the students

(v) Entry standards and selection for admission of students

(vi) Motivation and enthusiasm of faculty

(vii) Qualifications and activities of faculty members

(viii) Infrastructure facilities

(ix) Laboratory facilities

(x) Library facilities

(xi) Industry participation 
DOI: 10.17148/IARJSET.2021.8916

Process of Accreditation is shown in the flow chart

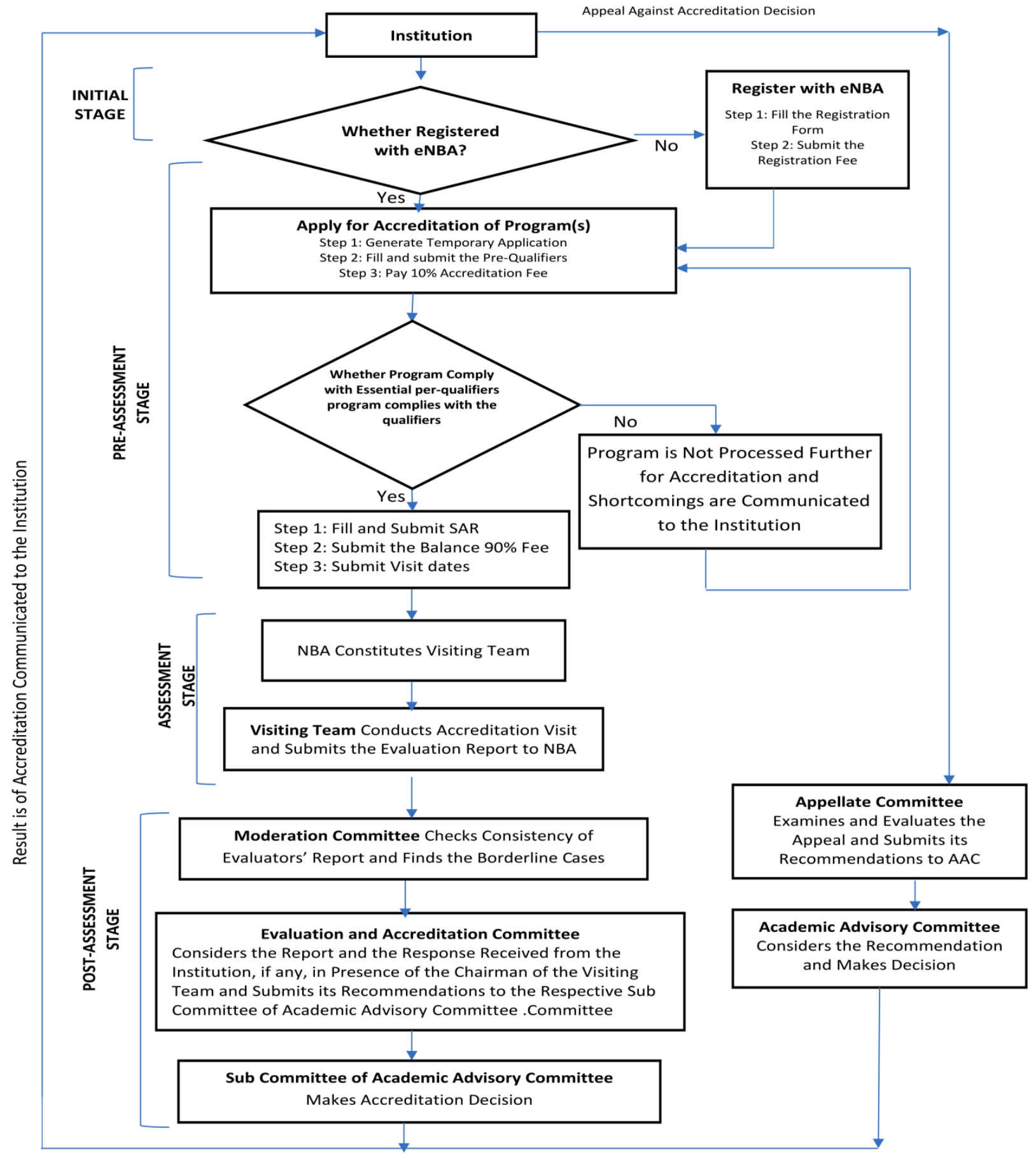

Fig 1: Flow Chart of Accreditation Process 


\section{International Advanced Research Journal in Science, Engineering and Technology}

Vol. 8, Issue 9, September 2021

DOI: 10.17148/IARJSET.2021.8916

\section{CONCLUSIONS}

Even though NBA accreditation process is somehow difficult, the accreditation of NBA helps Diploma level Polytechnics in India to know its strengths, weaknesses and opportunities. NBA accreditation helps institutes to get financial assistance from government agencies, private bodies etc. The accreditation gives Polytechnics a new sense of direction and identity to the institute as well as to the Students with following benefits.

- Global mobility, increased employability, and greater opportunity

- Better recognition for Institutions

- $\quad$ Continuous quality improvement

- $\quad$ Improved Student Performance

- $\quad$ Attracts employers attention

- A tone of credibility to the institutions

- $\quad$ Doubled faculty contribution, better results

- Better quality assurance to society

- Smarter students

- $\quad$ Easy MOU process

\section{ACKNOWLEDGMENTS}

The authors wish to express acknowledgments to those who contributed directly and indirectly in this paper. The views expressed in this paper are based on authors experience only. For any clarity one may refer to the concerned authorities.

\section{REFERENCES}

1. Manual for Accreditation Diploma Engineering Programs, National Board of Accreditation (NBA) New Delhi, November 2019.

2. https://www.ieagreements.org/accords/washington/

3. https://www.nbaind.org/

4. Short term training undergone in NBA Accreditation and SAR preparation Conducted by National Institute of Technical Teachers Training and Research Institute (NITTTR), KOLKATA, INDIA

5. Prequalifier for Diploma Engineering Programmes

6. Self Assessment Report Evaluation Guidelines

7. B. L. Gupta (2006) Governance and Management of Technical Institution, Concept Publishing Company New Delhi 